\title{
Quantitative Measurement of Serum Allergen-Specific IgE on Protein Chip
}

\author{
Tae-Eun Kim ${ }^{1}$, Seok-Won Park ${ }^{2}$, \\ Nam-Yun $\mathrm{Cho}^{3}$, Seung-Young $\mathrm{Choi}^{3}$ \\ Tai-Soon Yong ${ }^{4}$, Baek-Hie Nahm ${ }^{5}$, \\ SangSun Lee ${ }^{6}$, Geunwoong Noh ${ }^{7,8}$ \\ ${ }^{1}$ Molecular immunology \& Biochip Lab, Food Allergy Research Cen- \\ ter, Food BioTech Co. Ltd., Seoul \\ ${ }^{2}$ Dept. of Pediatrics, Wonju college of Medicine, Yonsei University, \\ Kangwon Province \\ ${ }^{3}$ Microarray Lab, Food Allergy Research Center, Food BioTech Co. \\ Ltd., Seoul \\ ${ }^{4}$ Dept. of parasitology, Yonsei University College of Medicine \\ ${ }^{5}$ Dept. of Biological Science, Myongji University, Kyungki Province \\ ${ }^{6}$ Dept. of Food and Nutrition, College of Life Science, Hanyang Uni- \\ versity, Seoul \\ ${ }^{7}$ Dept. of Allergy and Clinical Immunology, Seoul Allergy Clinic, 533 \\ Shinsa-dong, Kangnam-ku, Seoul, Korea 135-889 \\ ${ }^{8}$ Corresponding Author: Tel, +82-2-540-4905; \\ Fax,+82-2-511-2667; E-mail, atopy@ seoulallergy.com
}

Accepted 10 May 2002

Abbreviations : Dp, Dermatophagoides pteronyssinus

\begin{abstract}
Type I allergy is an immunoglobulin E (IgE)-mediated hypersensitivity disease inflicting more than quarter of the world population. In order to identify allergen sources, skin provocation test and $\lg \mathrm{E}$ serology was performed using allergen extracts. Such process identifies allergen-containing sources but cannot identify the disease-eliciting allergenic molecules. Recently, microarray technology has been developed for allergen-specific IgE detection using rolling circle amplification. This study was carried out to evaluate protein chip technology for the quantitative measurement and limits of sensitivity of multiple allergen-specific lgE by an immunofluorescence assay. Significance of positive calibrators was tested using purified human IgE. Dermatophagoides pteronyssinus (Dp), egg white, milk, soybean, and wheat were used as allergens and human serum albumin as negative control. Sensitivity and clinical efficacy of protein chip were evaluated using allergy immune serum for $\mathrm{Dp}$. The fluorescent intensities for purified human IgE as calibrator were well correlated with the concentrations of human IgE. Two-
\end{abstract}

fold dilution of serum allowed an optimal reaction with $\mathrm{Dp}(1 \mathrm{mg} / \mathrm{ml})$ at which serum Dp-specific IgE levels by protein chip were compatible with those by

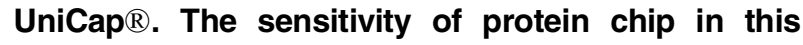
study was found at level of $1 \mathrm{lU} / \mathrm{ml}$ of IgE. Dp-specific IgE levels by protein chip correlated well with those of UniCap ${ }^{\circledR}$ by comparing 10 atopic dermatitis. Additional 18 sera were tested for above multiple antigens other than $\mathrm{Dp}$ and significant results were obtained for many antigens as well as $\mathrm{Dp}$. These results indicated that spotting of heterogeneous protein mixture on protein chip and the quantitative measurement of serum allergen-specific IgE levels using immunofluorescence assay can be successfully applied in the clinical laboratory for the diagnosis of allergy and could be applied to diagnosis of autoimmune and infectious diseases

Keywords: Crude Allergen Extracts, IgE, Protein Chip, Allergy

\section{Introduction}

Allergy is a state of immune dysregulation from Th1/Th2 balance and this state leads to overproduction of $\lg \mathrm{E}$ (Lacour, 1994) which plays a central role in allergy (Jujo et al., 1992). Avoidance of allergen is the first principle for the treatment of allergic diseases (David, 1992). However, clarifying the true causative agents that provoke allergy in individual patients still remains challenging task. Several methods such as skin prick test, patch test as well as identification of serum allergen-specific $\operatorname{lgE}$ are performed to suspect the causative allergen (Brown et al., 1979). Especially, identification of allergen-specific IgE in circulation is one of the most important methods for the diagnosis of allergic causes (Rance and Albero, 1984).

The allergen-specific antibody was the first reported by Millman (Millman et al., 1964). Discovery of allergen associated $\lg \mathrm{E}$ was reported by Isizaka (Isizaka et al., 1966) and Johansson and Bennich (Johansson and Bennich et al., 1967). IgE concentration is the lowest among the five antibody isotypes and the detection of antigen-specific $\lg \mathrm{E}$ is different from those to detect other antibodies. In consequence, serum IgE concentration is too low to detect by conventional immunoassay and to enhance the sensitivity of assay, radioallergosorbent test (RAST) was developed by Wide (Wide et al., 1967). However, due to the safety issues of isotope, it was replaced by fluorescence-tagged assay system (Tsay and 
Halpern et al., 1984). Recently, even enzyme immunoassay method has appeared to identify allergen-specific IgE (Ali et al., 1980).

Protein chip based on the established DNA microarray technology (Barinaga, 1991, Kim et al., 2001) was launched in 1999 (Lueking et al., 1999) by covalent linking of protein ligands to the activated silica surface of microscope slides (Gavin and Stuart, 2000). Possibility of protein microarray technology for characterization of variation patterns in hundreds of thousand different proteins in clinical application was explored (Brian et al., 2001). Protein chip based on the quantitative immunoassay for prostate-specific membrane antigen (PSMA) was recently developed (Xiao et al., 2000). Recently, allergen-specific IgE detections on microarrays using rolling circle amplification were reported (Mullenix et al., 2001, Wiltshire et al., 2000).

The allergen protein microarray technology allows the determination and monitoring of allergic patients' IgE reactivity profiles to large numbers of disease-causing allergens by using single measurements and minute amounts of serum.

In this study we have evaluated protein chip for the quantitative measurement of multiple allergen-specific $\mathrm{lg} \mathrm{E}$ by immunofluorescence detection methods and assessed sensitivity limitations and test conditions in parallel with commercially available test kit (UniCap $\left.{ }^{\circledR}\right)$ using well known allergens; Dermatophagoides pteronyssinus (Dp), egg white, milk, soybean, and wheat. Our finding showed that this method may change established practice in allergy diagnosis, efficacy test, prevention, and therapy.

\section{Materials and Methods}

\section{Patients and immune sera}

This study included a total of 57 atopic dermatitis patients who visited Seoul Allergy Clinic, Seoul, Korea from November 1, 2001 to March 31, 2002. They fulfilled the criteria of Hanifin and Rajka (Hanifin and Rajka, 1980). Venous blood samples were drawn from the antecubital vein and sera were stored at $-80^{\circ} \mathrm{C}$ until analysis. A parts of all sera were pooled as one for conditioning and calibration of protein chip. The blood levels of specific IgE for Dermatophagoides pteronyssinus (Dp), egg white, soybean, milk, and wheat were also measured by UniCap ${ }^{\circledR}$ method as described previously (Yunginger et al., 2000). Consent form was given to all subjects whose blood were tested.

\section{Protein preparation}

Fresh wheat grains and soy beans materials were washed, lyophilized, and milled into powder. The prepared powder, milk, and egg white were delipidated by extraction with $20 \%$ hexane solution. The delipidated powders were suspended in phosphate buffered saline (PBS: $4.3 \mathrm{mM} \mathrm{Na} \mathrm{HPO}_{4}, 1.4 \mathrm{mM} \mathrm{KH}_{2} \mathrm{PO}_{4}, \mathrm{pH} 7.4$ containing $137 \mathrm{mM} \mathrm{NaCl}$ and $2.7 \mathrm{mM} \mathrm{KCl}$ ) at a $1: 3$ weight ratio, stirred for several hours at $4^{\circ} \mathrm{C}$, and insoluble resides were removed by centrifugation at $20,000 \mathrm{~g}$. Most of the proteins in supernatant precipitated with $70 \%$ saturation of ammonium sulfate were collected by centrifugation, then precipitates were dissolved in PBS, dialyzed against distilled water, and lyophilized. These proteins were kept at $-80^{\circ} \mathrm{C}$ till use. Delipidated egg white and milk proteins were prepared in a similar manner. Allergen extracts of Dp were kindly donated from Institute of Allergy and Department of Parasitology, Yonsei University, College of Medicine. Purified human IgE (Chemicon, Temecula, CA, USA) and human serum albumin was obtained from Sigma, (St. Louis, MO, USA)

\section{Preparation of protein chip by spotting crude allergen extracts}

For spotting, protein extracts were dissolved in PBS containing $40 \%$ glycerol at a concentration of $1 \mathrm{mg} / \mathrm{ml}$ and $10 \mu \mathrm{l}$ aliquots were plated into each 384-well plates. Microsys 4100 (Cartesian, Irvine, CA, USA), a robotic microarrayer of spray type spotted $10 \mathrm{nl}$ of the protein solutions in an ordered array onto nitrocellulose membrane on slides at a $1500 \mu \mathrm{m}$ spacing. $\mathrm{FAST}^{\mathrm{TM}}$ slides (Schleicher \& Schull, Dassel, Germany) to which nitrocellulose membrane binds were used for spotting. The resulting protein chips were sealed in a slide box and stored at $4^{\circ} \mathrm{C}$

\section{Reaction and detection}

The arrays were briefly rinsed in a $3 \%$ bovine serum albumin (BSA) solution containing PBS and $0.1 \%$ Tween20 to remove unbound proteins. Protein chips were immersed into a 3\% BSA solution containing PBS and $0.02 \%$ sodium azide for blocking unreacted sites for overnight at $4^{\circ} \mathrm{C}$. Protein chips were then washed three times with PBS containing 0.1\% Tween-20 (washing buffer). These prepared protein chips were incubated with patients sera for $1 \mathrm{~h}$ in a chamber with shaking rotor, washed three times with washing buffer, and incubated with biotin-conjugated anti-human IgE (Vector, Burlingame, CA, USA) for $1 \mathrm{~h}$ at room temperature, washed three times with the washing buffer, and incubated with Cy3-conjugated streptavidin (Sigma, St. Louis. MS) for one hour, and washed three times with washing buffer. The reacted chips were spin-dried and scanned in Axon Laboratories (Palo Alto, CA, USA) scanner (Palo Alto, CA, USA) using $532 \mathrm{~nm}$ laser. The fluorescence intensities were measured in the Cy3specific channels at each spot using GenePix Pro (Axon Laboratories). 


\section{Significance of protein chip for the identification of allergen-specific IgE}

For calibration, purified human IgE solutions serially diluted to $500,250,125,62.5,31.3$, and $15.6 \mathrm{IU} / \mathrm{ml}$ were spotted. Human serum albumin was used as negative control and evaluated as $0 \mathrm{IU} / \mathrm{ml}$. The significance of positive calibrator was also tested using 29 patients sera by plotting the absolute fluorescence values for all spots.

To determine optimal antigen and serum level, Dp antigen serially diluted to $2,000,1,000,500,250,125$, and $62.5 \mu \mathrm{g} / \mathrm{ml}$ was spotted and tested with the pooled serum whose Dp-specific IgE level had been measured with UniCap ${ }^{\circledR}$ (Pharmacia \& Upjohn Diagnostics $A B$, uppsala, Sweden) method and serially diluted to 1-, 2-, 4-, 8-, 16-, and 32-fold, respectively. All tests were done in triplicate. Various protein mixture of four antigens spotted were also tested. Ten immune sera for $\mathrm{Dp}, 4$ for egg white and wheat, and 5 for soybean and milk were evaluated by both protein chip and UniCap $\mathbb{B}$ methods and estimation of IgE levels for each allergens using UniCap ${ }^{\circledR}$ as reference were compared with the results obtained with protein chip method and the statistical significances were evaluated.

Statistical analysis of data was performed using the SPSS version 7.0. Data is shown as mean \pm standard deviation. The correlation and linear regression was used in this study. Differences associated with a probability of $p<0.05$ were considered significant.

\section{Results}

\section{Significance of calibrator}

To determine optimal reaction conditions of the biotinstreptavidin coupled immune assay on a microarray, purified human IgE serially diluted from 500 to $15.6 \mathrm{IU} / \mathrm{ml}$ was used as a reference standard and human serum albumin as a negative control. Fluorescent Intensity of spots increased linearly with the rise of $\lg \mathrm{E}$ concentration. (Figure 1a) $\quad\left(y=1.5 x+711, \quad R^{2}=0.84, \quad P<0.05\right.$, Correlation Coefficiency $=0.93$ ) (Figure 1b). Some nonspecific fluorescence detected on the negative control was always below positive control and also constituted a part of the calibration curve.

\section{Optimal Reaction Conditions for Antigen Concen- tration and Serum Dilution}

To determine the optimal reaction conditions for allergen and serum levels, varying levels of $\mathrm{Dp}$ antigens were spotted on the protein chip and reacted with two-fold diluted pooled sera that are again serially diluted 1- to 32 -fold respectively. Results showed that 2-fold diluted sera gave optimal yield (Figure 2a). Data showed a corresponding fluorescence intensity decrease correlated (a)
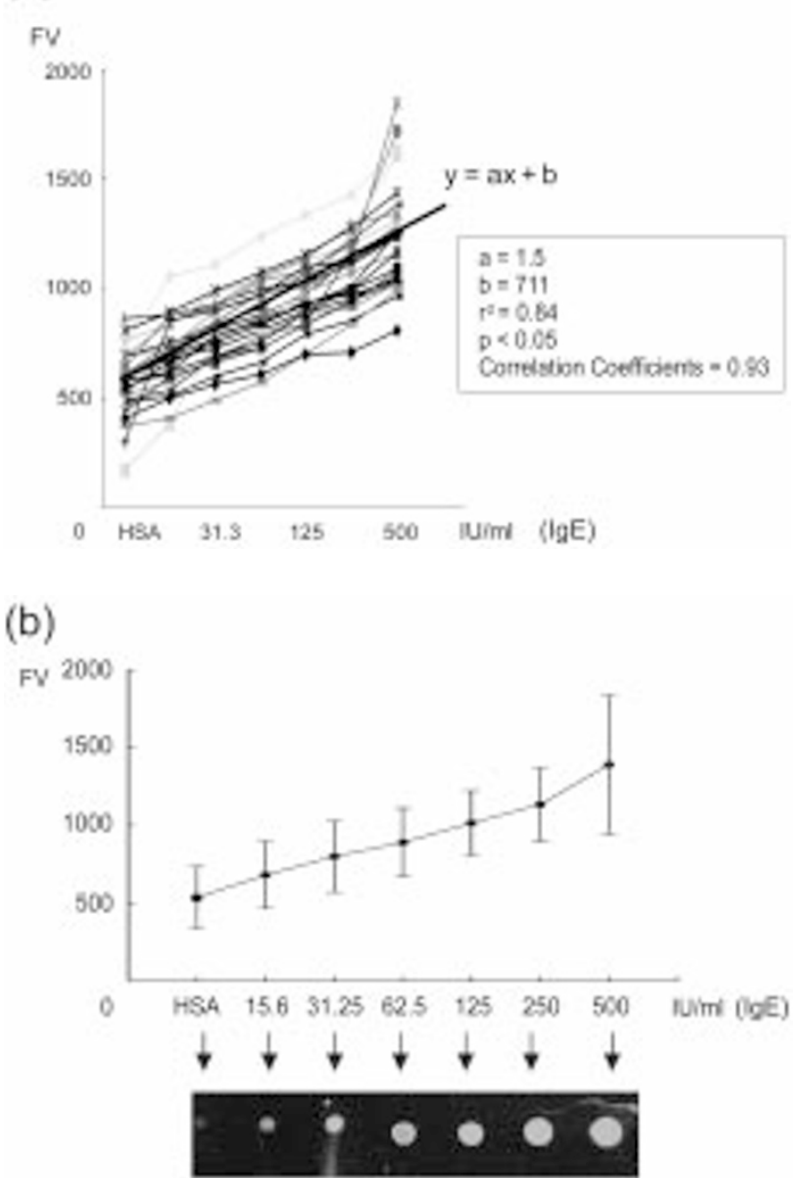

Figure 1. a) Calibration curve of protein chip which were spotted with purified human $\lg \mathrm{E}$ of variable $\lg \mathrm{E}$ concentrations as positive calibrator using 29 immune sera $\left(y=1.5 x+711, R^{2}=0.85, P<0.05\right.$, Correlation Coefficiency $=0.93)$, b) Calibration curve plotted with mean values of spots of variable human IgE concentrations showed a significant linearity. FV, fluorescent intensity values of spots; HAS, human serum albumin as a negative control. conc., concentration.

with the dilution. Spots containing Dp levels above $500 \mu \mathrm{g} / \mathrm{ml}$ reacted with appropriate sera lgE levels measured with the UniCap ${ }^{\circledR}$ method. To determine the antigen level on the chip spot whose reaction with $\lg \mathrm{E}$ sera compatible with the UniCap ${ }^{\circledR}$ mesurement, serially diluted $\mathrm{Dp}$ antigens were spotted from $2.0 \mathrm{mg} / \mathrm{ml}$ to $62.5 \mu \mathrm{g} / \mathrm{ml}$ and tested 7 times using pooled serum. Based on IgE calibration chart, Dp level of $1 \mathrm{mg} / \mathrm{ml}$ showed optimal response where protein chip spotted Dp-specific IgE levels became compatible with those levels measured by UniCap ${ }^{\circledR}$ method (Figure 2b).

\section{Antibody Dilution and Sensitivity}

Protein chips spotted with $1 \mathrm{mg} / \mathrm{ml}$ of Dp antigen were reacted with serially diluted sera to examine the sensitivity. Three sera with different Dp-specific IgE levels of $24.5,39.8$, and $67.3 \mathrm{IU} / \mathrm{ml}$, respectively were 
(a)

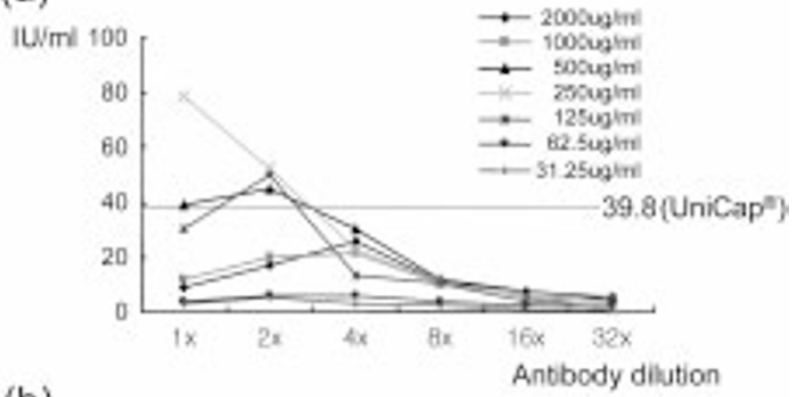

(b)

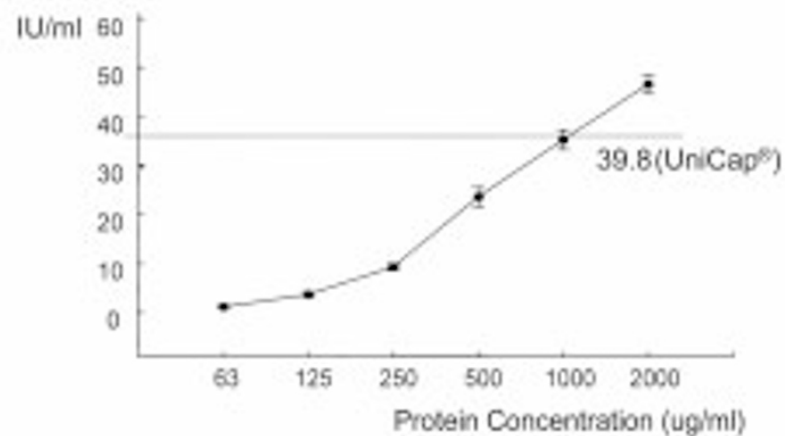

Figure 2. Optimal antigen concentration and proper serum dilution factor. a) Dermatophagoides pteronyssinus (Dp) antigens were serially diluted from $2.0 \mathrm{mg} / \mathrm{ml}, 1.0 \mathrm{mg} / \mathrm{ml}, 500 \mu \mathrm{g} / \mathrm{ml}, 250 \mu \mathrm{g} / \mathrm{ml}, 125 \mu \mathrm{g} / \mathrm{ml}, 62.5 \mu \mathrm{g} / \mathrm{ml}$, and $31.3 \mu \mathrm{g} / \mathrm{ml}$. Pooled sera was diluted to 1-, 2-, 4-, 8-, 16-, and 32-fold. Dotted line indicated the serum value of Dp-specific IgE. Proper dilution factor was 2 -fold. Spots of antigen concentration above $500 \mathrm{mg} / \mathrm{ml}$ showed significant

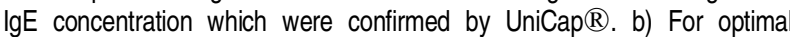
conditions for antigen concentration and serum dilution, serially diluted Dp antigen was spotted as $2.0 \mathrm{mg} / \mathrm{ml}, 1.0 \mathrm{mg} / \mathrm{ml}, 500 \mu \mathrm{g} / \mathrm{ml}, 250 \mu \mathrm{g} / \mathrm{ml}$, and $125 \mu \mathrm{g} / \mathrm{ml}, 62.5 \mu \mathrm{g} / \mathrm{ml}$, and $31.3 \mu \mathrm{g} / \mathrm{ml}$. Optimal concentration which resulted in Dp-specific lgE levels that were compatible with those by

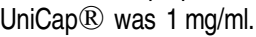

examined (Figure 3). The results showed sera dilution dependent near linear decrease response where 32-fold dilution of 39.8 and $67.3 \mathrm{lU} / \mathrm{ml}$ samples gave reactions within a linear reaction curve above the negative control. However, 32-fold dilution of the $24.5 \mathrm{IU} / \mathrm{ml}$ sample showed reacted spot below the negative control level. Based these results, the sensitivity limit of protein chip can reach to $1 \mathrm{IU} / \mathrm{ml} \mathrm{IgE}$ level.

\section{Clinical significance of protein chip}

The experimental and clinical relevance for the quantitative measurement of Dp-specific IgE using protein chip was evaluated using 10 immune sera containg Dp antigen. Reaction was carried out with Dp antigen level at $1 \mathrm{mg} / \mathrm{ml}$ and two-fold diluted sera. The results were compared with those measured by UniCap ${ }^{\circledR}$ method. The results by protein chip well correlated with those of UniCap ${ }^{\circledR}(y=1.11 \times-0.23$, $R^{2}=0.98, \quad P<0.05, \quad$ Correlation Coefficiency $=0.99$ )

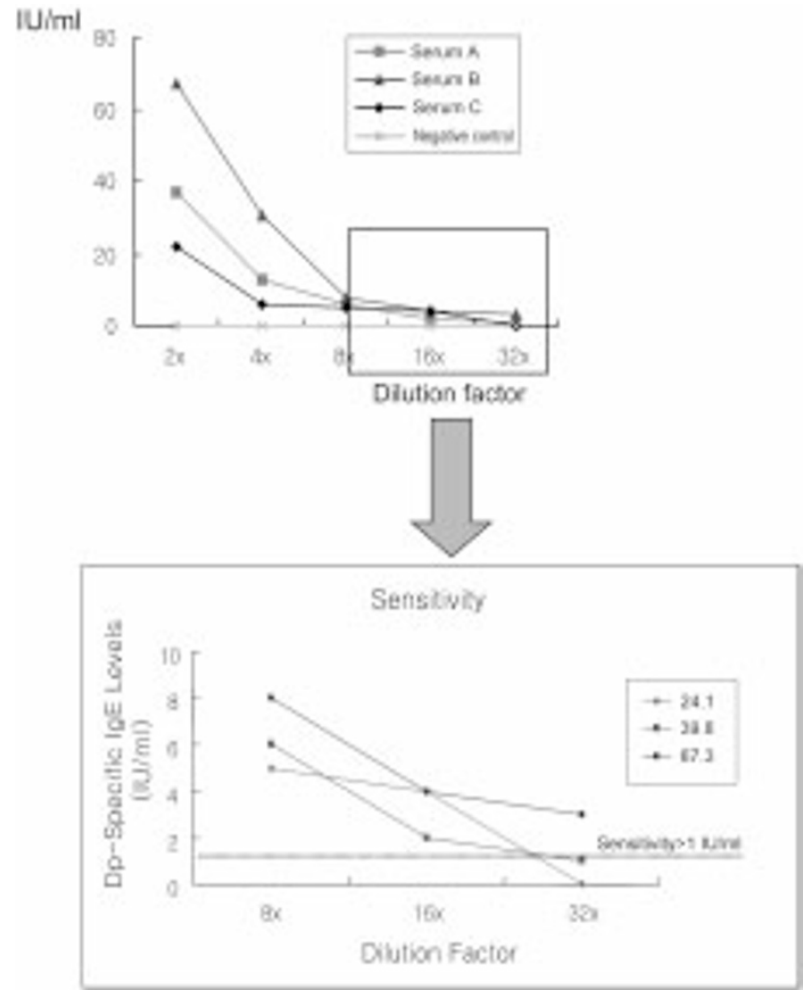

Figure 3. Antibody dilution effects and sensitivity of protein chip. Three sera with known Dermatophagoides pteronyssinus (Dp)-specific lgE levels were tested by diluting serially in this study. The sensitivity of protein chip in this study is over $0.5 \mathrm{IU} / \mathrm{ml}$. Actual sensitivity for clinical use is over $1 \mathrm{IU} / \mathrm{ml}$ because sera.

(Figure 4a). The results were classified according to grading system. Especially, grading of Dp-specific IgE levels by protein chip in this study matched well with those by UniCap $\AA\left(y=1.02 \times-0.12, R^{2}=0.98, P<0.05\right.$, Correlation Coefficiency $=0.99$ ) (Figure $4 \mathrm{~b}$ ). Multiple allergen-specific $\operatorname{lgE}$ levels by protein chip and by UniCap ${ }^{\circledR}$ were compared (Figure 5a) and well correlated with each other by statistical analysis $(y=0.99 \times-0.56, \quad R 2=0.95, \quad P<0.05, \quad$ Correlation Coefficiency $=0.97$ ) (Figure $5 b)$.

\section{Discussion}

Protein chip array method was applied for the quantitation of multiple allergen-specific IgE in this study by immunofluorescence assay. Examination of protein chips spotted with varying concentrations of purified human IgE as a reference gave fluorescent intensities values closely parallel with its concentrations (Figure 1). Such results suggested that an application of protein chip by immunofluorescence assay for the quantitative 
(a)

\begin{tabular}{ccc}
\hline & \multicolumn{2}{c}{ D.P } \\
\cline { 2 - 3 } Test sample & i-chip & UniCAP \\
Total (11) & $(I \mathrm{U} / \mathrm{ml})$ & $($ IU/ml) \\
\hline Sample 1 & 140 & 120 \\
Sample 2 & 41 & 48.5 \\
Sample 3 & 0 & 0.31 \\
Sample 4 & 3 & 1.41 \\
Sample 5 & 17 & 6.48 \\
Sample 6 & 0 & 0.2 \\
Sample 7 & 0.5 & 0.38 \\
Sample 8 & 45 & 47.4 \\
Sample 9 & 0 & 0 \\
Sample10 & 0.34 & 0.3 \\
Sample11 & 0 & 0.2 \\
\hline
\end{tabular}

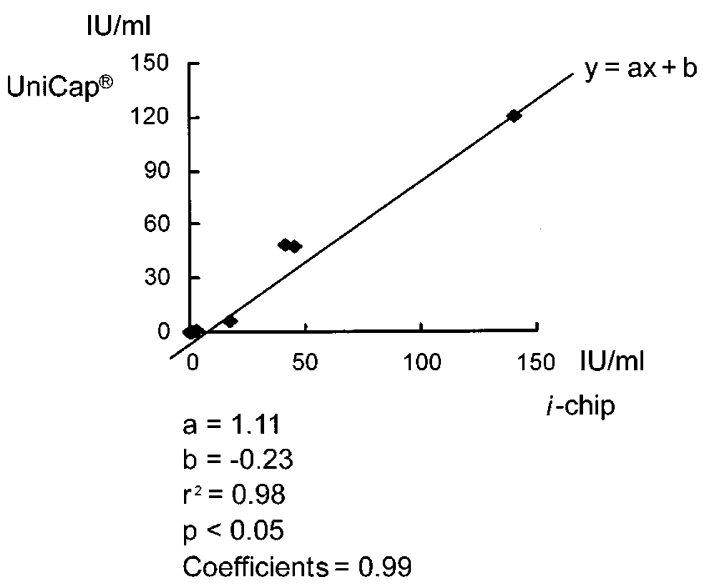

(b)

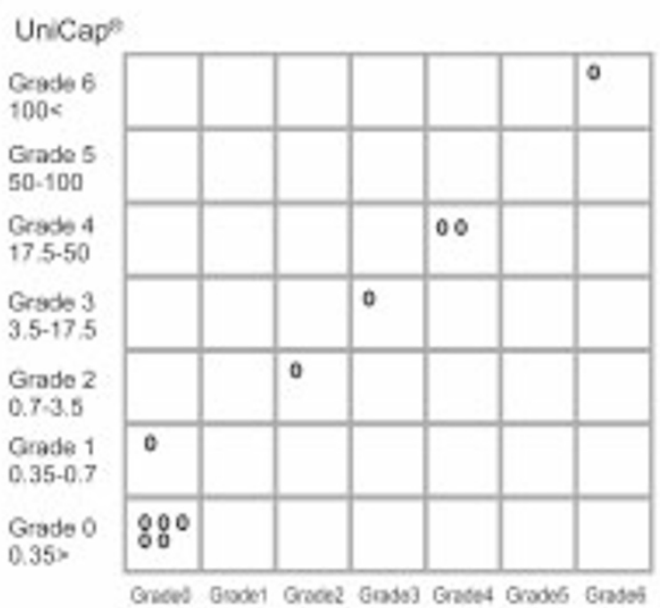

chip

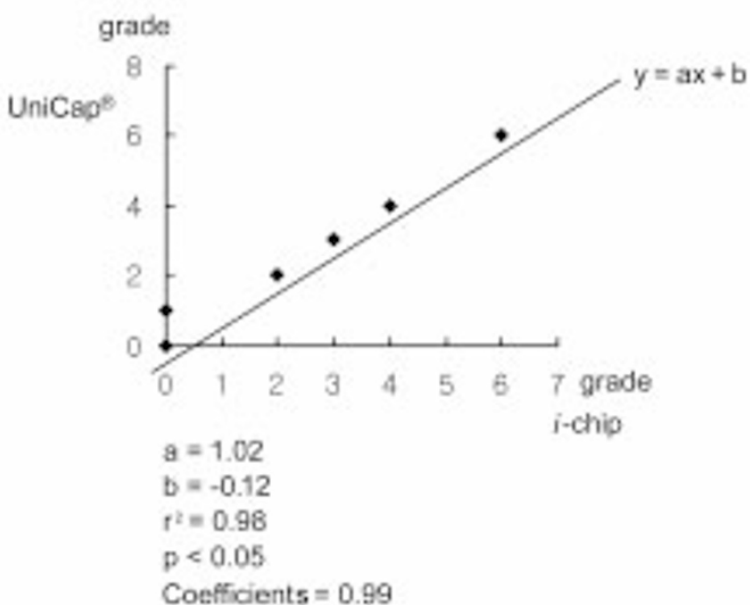

Figure 4. Correlation of the serum Dermatophagoides pteronyssinus (Dp)-specific lgE levels with those by UniCap $\AA$. a) Serum Dp-specific lgE levels by protein chip in this study were significantly correlated with those by UniCap $\mathbb{R}(p<0.05)$ using 10 Dp-allergy immune sera $\left(y=1.11 x-0.23, R^{2}=0.98, P<0.05, C o r r e l a t i o n\right.$

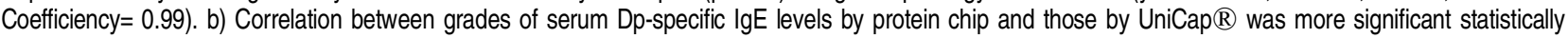
$(y=1.02 x-0.12, R 2=0.98, P<0.05$, Correlation Coefficiency $=0.99)$.

measurement of allergen-specific IgE was possible.

The spotted antigen level at $1 \mathrm{mg} / \mathrm{ml}$ was found to yield result compatible with the serum Dermatophagoides pteronyssinus (Dp)-specific lgE levels by UniCap ${ }^{\circledR}$ method (Figure 2). The level appeared to be much higher in comparison with concentrations used in enzymelinked immunosorbent assay (ELISA) or in other protein chip (Mullenix et al., 2001). The higher IgE levels were detected at the higher protein concentration of spotting suggest that actual antigen level might be much less in the crude antigen extracts used for spotting. The high concentration $(1 \mathrm{mg} / \mathrm{ml})$ was selected for spotting. The two-fold dilution of sera reduces the serum volume requirement for analysis.

Sensitivity of protein chip for serum Dp-specific IgE was found to be at $1 \mathrm{IU} / \mathrm{ml}$ for clinical use (Figure 3 ) comparing with $0.35 \mathrm{IU} / \mathrm{ml}$ of UniCap ${ }^{\circledR}$. Dp-specific $\lg \mathrm{E}$ levels of less than $1 \mathrm{IU} / \mathrm{ml}$ were classified as Grade I (Tsay and Halpern, 1984). For milk allergy, $7.5 \mathrm{IU} / \mathrm{ml}$ is the minimum allergen-specific IgE level for clinical application (Sampson, 2001). The sensitivity of protein chip is not a single issue for clinical use. Especially, in clinical fields, grading rather than absolute value of allergen-specific IgE is more useful. Not only the serum Dp-specific $\lg E$ concentration but also the grades of $\lg E$ levels by protein chip well-correlated with those of UniCap ${ }^{\circledR}$ (Figure 4). Moreover, the multiple allergenspecific $\lg E$ detection other than $\mathrm{Dp}$ was also significant. To enhance the sensitivity of protein chip, either selective enrichment of serum IgE concentration or more sensitive IgE coupled detection methods need to be developed. 

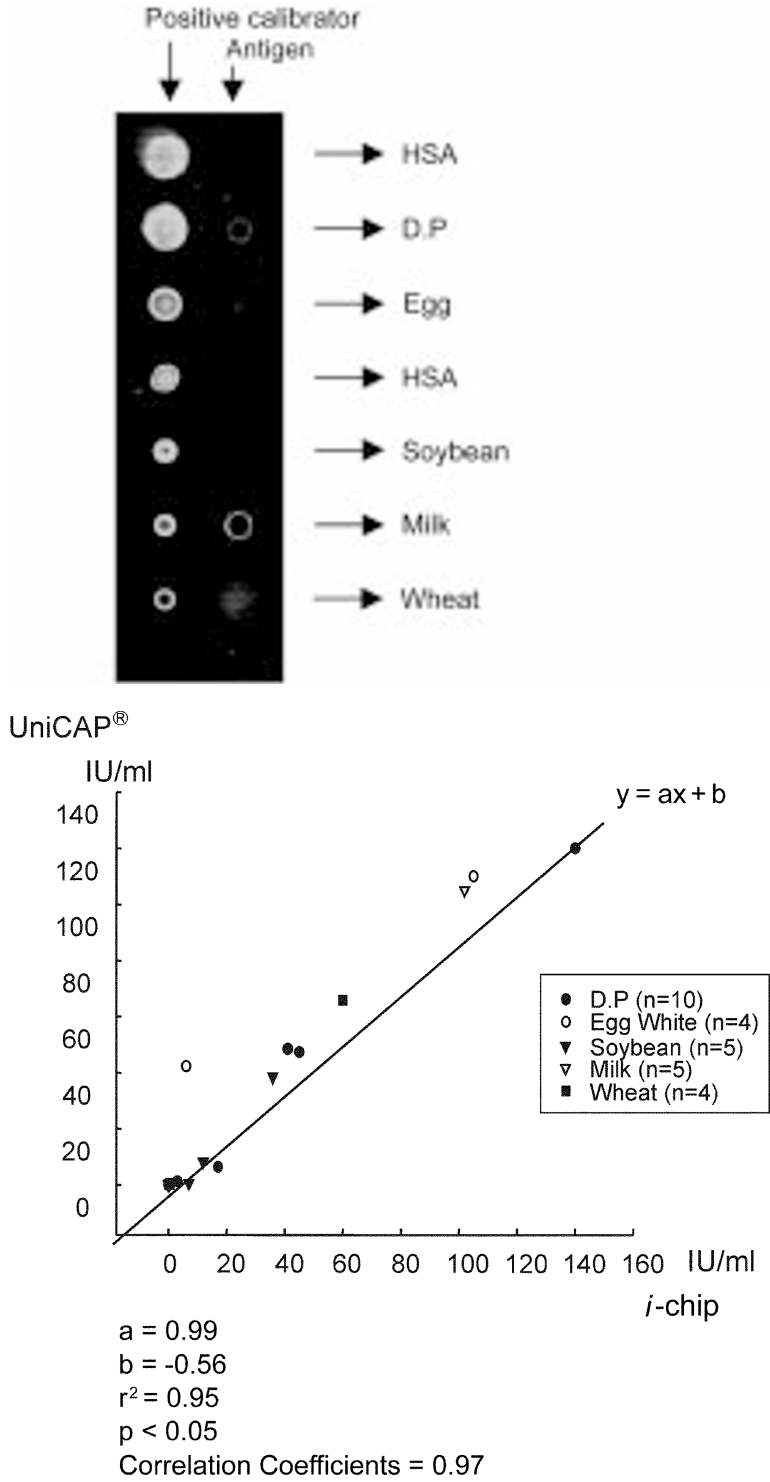

Figure 5. The quantitation of multiple serum allergen-specific $\operatorname{lgE}$. a) Scan of protein chip for the analysis of multiple allergen-specific IgE. Multiple allergen of Dermatophagoides pteronyssinus (Dp), egg white, milk, soybean, and wheat were spotted at a concentration of $1 \mathrm{mg} / \mathrm{ml}$ and reacted with sera of $2 x$ dilution. Cal, calibrator, b) Correlation of the serum allergen-specific $\lg E$ levels by protein chip with those by UniCap $\mathbb{R}\left(y=0.99 x-0.56, R^{2}=0.95\right.$, $P<0.05$, Correlation Coefficiency $=0.97$ ).

The avoidance of allergen is the primary principle of treatment and the causative controls are the most important for treatment of allergy (David, 1992). For this purpose, wider array of allergens from foods to environmental sources to which patients are exposed have to be tested for the diagnosis and avoidance therapy of allergy. However, such wide spectrum of allergens have not been tested because of the needs for a large quantity of blood samples and high cost by the available detection methods.
Protein chip may solve the limitations of conventional methods such as RAST or FAST with its several essential advantages such as efficiency, low cost and a little sample quantity for tests regardless of items to be tested as well as capability of simultaneously testing many kinds of items (Nelson, 2000). It may change established practice in allergy diagnosis, efficacy test, prevention, and therapy. Using protein chip, the tests for newborn or cord blood will be possible for many kinds of items without limitations in sample quantity.

Until now, protein chip was cautiously applied to identify antibodies or antigens using purified protein or purified antibody (Xiao et al., 2000). The heterogeneous protein mixture was used for spotting in this study. Heterogeneous protein mixture of crude antigen extracts rather than several purified allergens are more proper for the diagnostic purpose in allergy because all protein components in protein extracts possibly played a role as allergens. Use of heterogeneous protein mixture and detection of reacting antibody to components of the heterogeneous protein mixture is a marked advance in protein chip technology. Although human serum was used in pre-clinical tests (Schneider, 2000), human serum was used for the clinical diagnostic purpose for the analysis of allergen-specific lgE levels in this study. Spotting of heterogeneous protein for protein chip and use of serum directly for tests might be the most important factors for the clinical application of protein chip in other clinical fields. Serum total IgE is too low in concentration to detect by conventional methods in sera. Moreover, allergen-specific IgE is extremely low. The possible quantitative measurement of serum allergen-specific $\lg E$ is an important progress in protein chip technology. Recently, allergen-specific IgE detection on microarrays using rolling circle amplifiction was tried to solve this problem of sensitivity for IgE detection (Wiltshire et al., 2000, Mullenix et al., 2001,). In the report, pin-tool type microarrayer was used for spotting. Pin-type microarrayer is a semi-quantitative machine for the control of spotting volume. Protein concentration was the only factor to control for spotting and conditioning. From these reason, they might use the detection method of rolling circle amplification. However, spray-type microarrayer was used in this study. Both volume and concentration were controllable for conditioning of protein chip for spotting. For the exact conditioning of immunoassay, volume is an important factor to control as well as concentration of solution. Resultant conventional immunofluorescent assay was successful for the quantitative measurement of allergenspecific IgE in this study. Lastly we have demonstrated that the quantitative measurement of multiple allergenspecific IgE on a protein chip simultaneously. Before the appearance of protein chip, it was impossible to test multiple measurement in a well or in a test tube. However, in this study, the quantitation of multiple 
allergen-specific IgE on a protein chip was successfully achieved with the statistically significant results of every items (Figure 5).

In conclusion, protein chip using immunofluorescence assay is an useful and effective method for the quantitative measurement of multiple serum allergenspecific IgE in allergy filed. Further investigation might be needed and more application to other clinical fields and other diseases might be possible.

\section{Acknowledgements}

This research was supported by Grant for IMT-2000 Project of Ministry of Health \& Welfare, 2002(Grant No; 01-PJ11PG9-01BT00A-0046) and Technological Evaluation Development Business for SMEs 2002 (Grant No; Seoul 43). Especially, I would like to express my deep and lovely appreciation to Wha-Jung Ji (President of Food BioTech Co. Ltd.) and special thanks to Chein-Soo Hong (Head of Institute of Allergy, Yonsei University. college of Medicine), to Hyun Joong Kim and Hyun Jeong Lee (Corporate Planning and Business Coordination Office, Food BioTech Co. Ltd.) for their excellent coordination of this research project.

\section{References}

Ali M, Nalebuff DJ, Fada R, Fayemi AO. Correlation of the diagnostic skin test with the immunoperoxidase assay in ragweed hypersensitivity. Ann Allergy 1980;45:63-66

Barinaga M Will: "DNA chip" speed genome initiative. Science 1991;253:1489

Brian B Haab, Maitreya J Dunham, Patrick O Brown. Protein microarrays for highly parallel detection and quantitation of specific proteins and antibodies in complex solutions. Genome Biology 2001;2:research0004.1-0004.13

Brown WG, Halonen MJH, Kattenborn WT, Barbee RA. The relationship of respiratory allergy, skin test reactivity, and serum IgE in a community population sample. J Allergy Clin Immunol 1979;63:328-35

David TJ. Extreme dietary measures in the management of atopic dermatitis in childhood. Acta Derm Venereol (Stockh) 1992;176:113-16

Hanifin JM, Rajka G. Diagnostic features of atopic dermatitis. Acta Derm Venereol 1980;92(Suppl) :4-47

Ishizaka K, Ishizaka T, Hornbrook MM. Physico-chemical properties of human reagenic antibody. IV. Presence of a unique immunoglobulin as a carrier of reagenic activity. $\mathrm{J}$ Immunol 1966;97:75-85

Johansson SGO, Bennich $\mathrm{H}$. Immunological studies of an atypical (myeloma) immunoglobulin. Immunology 1967;13:381-94

Jujo K, Renz H, Abe J, Gelfand EW, Leung DYM. Decreased interferon gamma and increased interleukin-4 production in atopic dermatitis promotes IgE synthesis. J Allergy Clin Immunol 1992;90:323-31

Kim JH, Kim HY, Lee YS, A novel method using edge detection for signal extraction from cDNA microarray image analysis. Exp Mol Med. 2001;33(2):83-8.

Lacour M. Acute infections in atopic dermatitis a clue for a pathogenic role of a Th1/Th2 imbalance. Dermatology 1994;188:255-57

Lueking A, Horn M, Eickhoff $\mathrm{H}$, Bussow K, Lehrach $\mathrm{H}$, Walter G. Protein Microarrays for gene expression and antibody screening. Anal Biochem 1999;270:103-11

MacBeath G and Schreiber SL. Printing Proteins as Microarrays for high-throughput function determination. Science 2000;289:1760-63

Millman M, Wolter GH, Millman J, Rosen R. A new in vitro test for the detection of antibody in sera of patients allergic to Lolium multiforum (Italian rye grass). Ann Allergy 1964;22:136-45

Mullenix MC, Wiltshire S, Shao W, Kitos G, Schweitzer B. Allergen-specific IgE detection on microarrays using rolling circle amplification: Correlation with in vitro assays for serum IgE. Clin Chem 2001;47:1926-29

Nelson RW, Nedelkov D, Tubbs KA. Biosensor chip mass spectrometry: a chip-based proteomics approach. Electrophoresis 2000;21:1155-63

Rance HA, Albero R. Comparison of results of skin tests, RAST, and double-blind, placebo-controlled food challenges in children with atopic dermatitis. J Allergy Clin Immunol 1984;74:26-33

Sampson HA. Utility of food-specific az IgE concentrations in predicting symptomatic food allergy. J Allergy Clin Immunol 2001;107:891-96

Schneider BH, Dickinson EL, Vach MD, Hoijer JV, Howard LV. Highly sensitive optical chip immunoassays in human serum. Biosens Bioelectro 2000;15:13-22

Tsay YG, Halpern GM. IgE fluoroallergosorbent (IgE FAST ${ }^{T M}$ ) test: Concept and clinical applications. Immunol Allergy Prac 1984;6:169-74

Wide $\mathrm{C}$, Bennich $\mathrm{H}$, Johansson SGO. Diagnosis of allergy by an in vitro test for allergy antibodies. Lancet 1967;2:1105-7

Wiltshire S, O'Malley S, Lambert J, Kukanski K, Edgar D, Kingsmore SF, Schweitzer B. Detection of multiple allergenspecific IgEs on microarrays by immunoassay with rolling circle amplification. Clin Chem 2000;46:1990-93

Xiao Z, Jiang X, Beckett ML, Wright GL Jr. Generation of a baculovirus recombinant prostate-specific membrane antigen and its use in the development of a novel protein biochip quantitative immunoassay. Protein Expr Purif 2000;19:12-21

Yunginger JW, Ahlstedt S, Eggleston PA, Homburger HA, Nelson HS, Ownby DR, Platts-Mills TA, Sampson HA, Sicherer SH, Weinstein AM, Williams PB, Wood RA, Zeiger RS. Quantitative IgE antibody assays in allergic disease. J Allergy Clin Immunol 2000;105:1077-84. 